\title{
Impact of antioxidative supplementation on semen quality according to MSOME criteria
}

\section{Improvement of semen parameters by dietary supplement}

\author{
Richardson $\mathrm{Ajayi}^{1}{ }^{\text {, Jasmin Okhowat }}{ }^{2}$, Dietmar Spitzer ${ }^{2}$, Birgit Schechinger ${ }^{2}$, Nicolas Herbert Zech ${ }^{2,3}$ \\ ${ }^{1}$ The Bridge Clinic, Lagos, Nigeria \\ ${ }^{2}$ IVF Centers Prof Zech, Austria \\ ${ }^{3}$ The study was carried out at the IVF Center Prof. Zech - Bregenz (Austria)
}

\begin{abstract}
Purpose: To investigate the influence of an oral antioxidative and micronutrient supplementation on semen quality assessed by MSOME (motile sperm organelle morphology examination) criteria in a collective of in vitro fertilization (IVF) patients.
\end{abstract}

Methods: Sperm analysis of 160 IVF patients was evaluated 2-12 months before undergoing IVF/IMSI (intracytoplasmic morphologically selected sperm injection) cycle. The following parameters were analyzed: semen volume, sperm concentration, motility and morphology according to MSOME criteria. Patients were grouped according to the WHO criteria into normozoospermic, oligoasthenoteratozoospermic (OAT) oligo- and asthenozoospermic men, respectively. Between first and second semen analysis, patients were treated orally with a dietary antioxidative supplement. The Student's t-test was used to evaluate the significance of data.

Results: In the total number of patients we found a significant reduction in the percentage of immotile sperms and a highly significant increase of total sperm motility after antioxidative therapy. We also observed substantial improvement of motility, the sperm concentration as well as sperm morphology (according to MSOME criteria) in the semen of oligozoospermic, asthenozoospermic and OAT patients. For normozoospermic patients, we found almost no significant increase in sperm parameters.

Conclusions: The results display a considerable improvement in semen quality, such as motility, sperm concentration and morphology after dietary supplementation, notably in IVF patients with poor semen quality. Amelioration of sperm quality of IVF patients can have a crucial impact in assisted reproductive technology (ART). Our findings suggest that micronutrient supplementation might be generally beneficial for semen quality in men undergoing ART, but mostly in those with a higher grade of alterations in their sperm parameters. The suggested mode of action is probably due to a decline of oxidative stress.

Keywords: semen quality, spermatozoa, morphology, MSOME, IMSI, oxidative stress, antioxidative supplementation, male infertility, assisted reproductive technologies, IVF, ART

\section{RESUMO}

Objetivo: investigar a influência de uma suplementação oral de antioxidantes e micronutrientes na qualidade do sêmen avaliado por MSOME em pacientes de fertilização in vitro (FIV) .
Métodos: análise de esperma de 160 pacientes de FIV foi realizada de 2-12 meses antes do ciclo FIV / IMSI (injeção intracitoplasmática de espermatozóides morfologicamente selecionados).Foram analisados os seguintes parâmetros: volume seminal, a concentração de espermatozóides, motilidade e morfologia de acordo com critérios MSOME. De acordo com os critérios da OMS, os pacientes foram agrupados em normozoospérmicos, oligoastenoteratozoospérmicos (OAT) e oligo-astenozoospérmicos, respectivamente. Entre a primeira e a segunda análise seminal, os pacientes foram tratados oralmente com um suplemento antioxidante. $O$ teste $t$ de Student foi utilizado para avaliar a significância dos dados.

Resultados: No total de pacientes houve uma redução significativa na porcentagem de espermatozóides imóveis e um aumento muito significativo da motilidade espermática total após terapia antioxidante. Observamos, também melhoria substancial da motilidade e na concentração de espermatozóides, bem como na morfologia (de acordo com critérios MSOME) dos pacientes astenozoospérmicos, oligozoospérmicos e OAT. Nos pacientes normozoospérmicos, encontramos quase nenhum aumento significativo nos parâmetros seminais.

Conclusões: Os resultados exibem uma melhoria significativa na qualidade do esperma, tais como a motilidade, concentração espermática e morfologia após a suplementação dietética em pacientes de fertilização in vitro com semen de baixa qualidade. A melhora da qualidade do esperma dos pacientes de FIV pode ter um impacto crucial na tecnologia de reprodução assistida (ART). Nossos resultados sugerem que a suplementação de micronutrientes pode ser benéfica para a qualidade do esperma em em homens submetidos a ART, mas principalmente naqueles com maior grau de alterações nos parâmetros seminais. O modo de ação sugerido é provavelmente devido a uma diminuição do estresse oxidativo.

Palavras-chave: qualidade seminal, espermatozoides, morfologia, MSOME, IMSI, estresse oxidativo, suplementação antioxidante, infertilidade masculina, reprodução assistida, FIV

\section{INTRODUCTION}

According to the World Health Organization (WHO), the total proportion of male-factor-related infertility comes to $46 \%$. Not surprisingly, numerous publications have suggested a worldwide decline in sperm count and other semen parameters (Nelson \& Bunge, 1974; Carlsen et al., 1992).In contrast to these findings, other studies observed no, or only decline of a few parameters 
(Rasmussen et al., 1997; Acacio et al., 2000). However, there is strong evidence that several subpopulations or certain countries in the world do suffer from decreased human fertility. Even though reasons for this are numerous and varying, one of the contributing factors clearly is environmental pollution (Oliva et al., 2001; Multiger \& Olivan, 2002). This is particularly true for countries with fast economic and industrial growth, such as the BRICS states (Brazil, Russia, China, South Africa). Here environmental protection and work safety policy is still permissive, cities are growing unrestrainedly and/or the agricultural sector is the main branch of the economy. According to the annual list of the world's worst polluted places presented by the Blacksmith institute, seven of the top ten of the world's worst polluted regions in 2007 could be found in China, India, Russia and South America (Blacksmith Institute, 2007). There are reasons to assume that this increasing environmental pollution and the broad usage of biocides not only affects human health in general, but also fertility in particular, partly due to endocrine disruption but also due to increased oxidative stress. Several reviews and studies from animal model systems as well as population studies in areas of heavy environmental pollution in South America and China support suggestions that human fertility declines in these regions (Mohallem et al.,

2005; Lichtenfels et al., 2007; Koifman et al., 2002; Huang et al., 2010). Regarding male fertility, reproduction does not only require normal sperm parameters in terms of sperm concentration and motility, but also the integrity of the genetic constitution of the spermatozoa. Although assisted reproductive technology (ART) has helped to overcome certain types of human infertility, the reproductive capacity of the gametes remains largely unaffected by the ART procedure. Given that the cellular repair mechanisms are restricted in the chromatin condensed mature sperm, intense exposure to ROS or other noxious substances does not only impair sperm membrane integrity and therefore motility and fertilization, but also affects the genetic constitution of the sperm. Even though it is not unequivocally clear to which extend oocytes can overcome sperm DNA damage after fertilization, several studies point out that a pro-oxidative state or diminished DNA integrity in the semen affects the developmental competence of the embryo (Silva et al., 2007; Agarwal \& Allamaneni, 2011). Exposure to toxic substances is widely known to affect sperm DNA integrity substantially. Furthermore, it was even shown that sperm DNA was hypermethylated in mice when exposed to particulate air pollution (Yauk et al., 2008). Although, epigenetic research is still a young topic in science and only few data concerning epigenetic modifications of sperm are available, broad alterations in DNA methylation are associated with infertility and consequences for the offspring (Jenkins \& Carrel, 2012). Failures in genome and/or imprinting failures in the epigenome are reflected by low semen quality. On the other hand, numerous studies have clearly demonstrated that improved sperm quality, in particular sperm's fine morphology and DNA integrity, contributes to a better outcome for IVF patients in terms of better fertilization- and implantation-, as well as a lower miscarriage rate and to the health of the offspring (Vanderzwalmen et al., 2008; Lewis and Simon, 2010; Bartoov et al., 2003). Conversely, these results indicate that impaired sperm quality affects fertilization, pregnancy and baby take home rate in a negative manner. Furthermore, beside all progress in the ART, it is of course still eligible to allow human reproduction done the natural way. For this reasons, it would be preferable to have adequate instruments to circumvent certain problems of infertility in the first place.

Even though it is still under debate, more and more studies from animal model systems and even clinical data implicate that lifestyle factors such as nutrition have a considerable effect on sperm quality, in particular with regard to the total antioxidative capacity of semen (Omu et al., 2008; Balercia et al., 2009). In accordance with this, studies have demonstrated a benefit of antioxidative and/or micronutritional supplementation (Omu et al., 2008; Balercia et al., 2009; Cifti et al., 2009). Furthermore, vitamin and or micronutrient intake was demonstrated to attenuate detrimental influences on semen quality in animal model systems such as exposure to toxic substances (Cifti et al., 2011). In concordance to these findings, infertile men were shown to have increased level of reactive oxygen species (ROS) in seminal plasma and spermatozoa, reduced antioxidative capacity (Zini et al., 1993) and increased number of mitochondrial DNA mutations or nuclear DNA fragmentation (Mahfouz et al., 2010; Kumar et al., 2009). Therefore, antioxidative nutrition is mostly regarded as a helpful tool to quench ROS and thereby improving sperm quality in humans or in laboratory animals, but not without controversy. This might be due to the - still - little clinical data, the effectiveness of different antioxidatives, the administered doses, the analyzed semen parameter(s), types of infertility and, probably, due to the heterogeneity of the studied subpopulations.

The study presented here aimed to examine whether semen quality (in particular the sperm morphology according to MSOME criteria and with regard to differences of male fertility) of IVF patients can be improved by a dietary supplementation comprising defined antioxidants.

\section{MATERIAL AND METHODS}

In the period from January 2008 to July 2011 a total of 160 patients from our IVF clinic in Bregenz (Austria) were included in this study. The semen samples of patients undergoing (intracytoplasmic morphologically selected sperm injection) IMSI cycles were analyzed with respect to several sperm parameters such as ejaculation volume, sperm concentration and sperm motility according to WHO criteria (WHO, 2010). Additionally, semen quality was assessed according to MSOME criteria (modified from Vanderzwalmen et al., 2008). Selection of spermatozoa was done at $6000 \times$ magnification under a Nomarski interferential Leica AM 6000 inverted microscope (Leica, Germany). Grade I sperm was defined by normal shape and size, no vacuoles or only small vacuole(s) $<4 \%$ of the sperm's head, grade II: normal shape and size but large vacuoles $>4 \%$ of the sperm's head, grade III: large vacuoles $>4 \%$ of the sperm's head and,additionally, abnormal shape and/or size of spermatozoa.

For our study patients were recruited according to foll wing criteria: They consented to have a dietary supplementation, they had no indication of azoospermia and did not have any known genetic reasons for impaired spermatogenesis (such as chromosomal aberrations or other genetic defects). Additionally, they were not exposed to irradiation or chemotherapy. After the first semen analysis patients were treated orally with a dietary supplement (Fertilovit $\circledast$ Mplus) for at least 2 month, one capsule twice daily (substances of content are given in Table 1). The different components of the preparation were described as beneficial for protecting sperms from oxidative 
Table 1. Substances of content for Fertilovit ${ }^{\circledR}$ Mplus $^{\text {. }}$

\begin{tabular}{lc}
\hline Content & Daily dose/ 2 capsules \\
\hline Vitamin C & $100 \mathrm{mg}$ \\
\hline Vitamin E & $100 \mathrm{mg}$ \\
\hline Folic acid & $500 \mathrm{\mu g}$ \\
\hline Zinc & $25 \mathrm{mg}$ \\
\hline Selenium & $100 \mu \mathrm{g}$ \\
\hline N-acetyl-L-cysteine & $50 \mathrm{mg}$ \\
\hline L-carnitine & $300 \mathrm{mg}$ \\
\hline Citrulline & $300 \mathrm{mg}$ \\
\hline Glutathione red. & $50 \mathrm{mg}$ \\
\hline Lycopene & $4 \mathrm{mg}$ \\
\hline Coenzyme Q10 & $15 \mathrm{mg}$ \\
\hline A daily intake 2 capsules
\end{tabular}

A daily intake of 2 capsules was recommended.

damage or having other supporting effects, respectively. The semen samples were examined by MSOME again after a 2-12 months course of antioxidative therapy (mean 3.5 months). No undesired side effects of the supplementary intake were noted so far.

The total patients' age ranged from 28 to 61 years (mean 39.2). Sperm concentration and percentage of motility were assessed according to the WHO criteria (WHO, 2010). According to these criteria patients were class-divided into normozoospermia (sperm concentration $15 \mathrm{Mio} / \mathrm{ml}$ and progressive motility $32 \%$ ), OAT (sperm concentration $<15 \mathrm{Mio} / \mathrm{ml}$ and progressive motility $<32 \%$ ) or patients, which revealed either oligozoospermia (sperm concentration $<15 \mathrm{Mio} / \mathrm{ml}$ ) or asthenozoospermia (progressive motility $<32 \%$ ). Data was expressed as mean \pm standard deviation for parametric variables and analyzed by Student's t-test.

\section{RESULTS}

According to these criteria, 65 patients were normozoospermic (NO), 42 men were referred to the OAT group, 20 patients had restrictions in sperm count (oligozoospermia) and 33 were referred as asthenozoospermic (see Table 2).

The mean age of the normozoospermic patients was 39.2, for OAT patients 39.2, oligozoospermic and asthenozoospermic men 38.7 and 39.2 years, respectively. By comparing the semen parameters of the first semen analysis, OAT patients revealed considerable lower total sperm motility in contrast to the other groups (total motility for OAT patients $21.8 \pm 21.1 \mathrm{vs}$. $63.4 \pm 12.0$ of normozoospermic patients and $52.9 \pm$ 15.6 for oligoand $36.1 \pm 16.9$ for asthenozoospermic patients (Table $2 a$ ).

The second semen analysis was performed within a period of 2 to 12 months of antioxidative supplementation in an IVF/IMSI cycle (mean: 3.2 month for OAT, 3.5 for normozoospermic patients and 3.4 month for oligo- and asthenozoospermic patients). After the dietary supplementation, we found remarkably less immotile sperm (grade d) and a significant increase in total motility in the total number of patients (see Table 2a).

Additionally, a highly significant increase in the progressive and total motility in the OAT group in the second semen analysis could be observed. The sperm concentration of the OAT patients also significantly raised (2.6 Mio \pm 4.9 vs. 6.7 Mio \pm 9.6 ).

Moreover, a significant increase in grade a and grade b sperm was observed, while the percentage of grade $d$ sperm (immotile sperm) was significantly decreased. Other alterations of semen parameters analyzed according to the WHO criteria in this subgroup with exception of the semen volume were not significant. Oligo- as well as asthenozoospermic patients revealed a significant higher percentage of class a sperm in the second semen analysis. Both subgroups also display an improvement of progressive and total motility, although not significant for the oligozoospermic patients. Nevertheless, sperm concentration in the oligozoospermic patient group has risen significantly. In contrast to this, alterations of semen parameters from normozoospermic patients showed a trend but without significance.

Regarding the sperm morphology according to MSOME criteria, we observed a significant increase of sperm with a low vacuolisation rate (grade I) and decrease of sperm with high vacuolisation rate and/or malformations (grade III) sperm in the total number of patients (Table $2 b$ ). A significant increase of grade I sperm was also found in the semen of oligo- or asthenozoospermic patients. For OAT patients we observed a significant decline in the percentage of grade III sperm. In contrast the percentage of grade I and grade II sperm was increased, although not significant for grade I. These results indicate that dietary supplementation might be beneficial not only for sperm motility, but also for sperm morphology and integrity (MSOME criteria) in distinct IVF patient groups.

Tabela 2b. Routine semen assessment before and after antioxidative supplementation.

\begin{tabular}{|c|c|c|c|c|c|c|c|c|c|c|c|c|c|c|c|c|}
\hline & & \multicolumn{3}{|c|}{ All patients } & \multicolumn{3}{|c|}{$\begin{array}{c}\text { Normozoospermic } \\
\text { patients }\end{array}$} & \multicolumn{3}{|c|}{$\begin{array}{c}\text { Oligozoospermic } \\
\text { patients }\end{array}$} & \multicolumn{3}{|c|}{$\begin{array}{l}\text { Asthenozoospermic } \\
\text { patients }\end{array}$} & \multicolumn{3}{|c|}{$\begin{array}{c}\text { OAT } \\
\text { patients }\end{array}$} \\
\hline & & $\begin{array}{c}\text { Before } \\
\text { treat } \\
\text { ment }\end{array}$ & $\begin{array}{l}\text { After } \\
\text { anti- } \\
\text { oxida } \\
\text { tive } \\
\text { intake }\end{array}$ & $\begin{array}{c}p- \\
\text { value }\end{array}$ & $\begin{array}{c}\text { Before } \\
\text { treat } \\
\text { ment }\end{array}$ & $\begin{array}{c}\text { After } \\
\text { anti- } \\
\text { oxida } \\
\text { tive } \\
\text { intake }\end{array}$ & $\begin{array}{c}p- \\
\text { value }\end{array}$ & $\begin{array}{c}\text { Before } \\
\text { treat } \\
\text { ment }\end{array}$ & $\begin{array}{l}\text { After } \\
\text { anti- } \\
\text { oxida } \\
\text { tive } \\
\text { intake }\end{array}$ & $\begin{array}{c}p- \\
\text { value }\end{array}$ & $\begin{array}{c}\text { Before } \\
\text { treat } \\
\text { ment }\end{array}$ & $\begin{array}{l}\text { After } \\
\text { anti- } \\
\text { oxida } \\
\text { tive } \\
\text { intake }\end{array}$ & $\begin{array}{c}p- \\
\text { value }\end{array}$ & $\begin{array}{c}\text { Before } \\
\text { treat } \\
\text { ment }\end{array}$ & $\begin{array}{l}\text { After } \\
\text { anti- } \\
\text { oxida } \\
\text { tive } \\
\text { intake }\end{array}$ & $\begin{array}{c}p- \\
\text { value }\end{array}$ \\
\hline & $\begin{array}{l}\text { Grade } \\
\text { I }\end{array}$ & $\begin{array}{c}5.1 \pm \\
5.4\end{array}$ & $\begin{array}{c}6.6 \pm \\
6.7\end{array}$ & $*$ & $\begin{array}{c}7.2 \pm \\
6.1\end{array}$ & $\begin{array}{c}8.3 \pm \\
6.3\end{array}$ & n.s. & $\begin{array}{c}3.4 \pm \\
3.2\end{array}$ & $\begin{array}{l}10.8 \pm \\
7.5\end{array}$ & * & $\begin{array}{c}5.1 \pm \\
5.2\end{array}$ & $\begin{array}{l}8.4 \pm \\
7.0\end{array}$ & * & $\begin{array}{c}2.6 \pm \\
4.0\end{array}$ & $\begin{array}{c}5.0 \\
\pm 7.2\end{array}$ & n.s. \\
\hline$\frac{\pi}{2}$ & $\begin{array}{l}\text { Grade } \\
\text { II }\end{array}$ & $\begin{array}{c}39.7 \pm \\
15.5\end{array}$ & $\begin{array}{c}42.9 \pm \\
14.6\end{array}$ & n.s. & $\begin{array}{c}44.4 \pm \\
13.0\end{array}$ & $\begin{array}{c}47.1 \pm \\
12.5\end{array}$ & n.s. & $\begin{array}{c}47.1 \\
\pm \\
12.2\end{array}$ & $\begin{array}{c}43.9 \pm \\
9.0\end{array}$ & n.s. & $\begin{array}{c}42.5 \pm \\
11.7\end{array}$ & $\begin{array}{c}41.8 \pm \\
11.6\end{array}$ & n.s. & $\begin{array}{c}26.9 \pm \\
15.7\end{array}$ & $\begin{array}{c}37.4 \\
\pm 15.8\end{array}$ & $* *$ \\
\hline 峁 & $\begin{array}{l}\text { Grade } \\
\text { III }\end{array}$ & $\begin{array}{c}55.2 \pm \\
18.1\end{array}$ & $\begin{array}{c}50.5 \pm \\
18.2\end{array}$ & $*$ & $\begin{array}{c}48.4 \\
\pm \\
15.6\end{array}$ & $\begin{array}{c}44.6 \pm \\
14.5\end{array}$ & n.s. & $\begin{array}{c}49.5 .0 \\
\pm \\
14.4\end{array}$ & $\begin{array}{c}45.3 \pm \\
10.2\end{array}$ & * & $\begin{array}{c}52.4 \\
\pm \\
13.1\end{array}$ & $\begin{array}{c}49.8 \pm \\
14.8\end{array}$ & * & $\begin{array}{c}70.5 \pm \\
17.7\end{array}$ & $\begin{array}{l}57.6 \\
\pm 20.1\end{array}$ & $* *$ \\
\hline
\end{tabular}

Oligoasthenoteratozoospermia was defined according to WHO criteria. OAT= oligoasthenoteratozoospermia; n.s. = not significant; $*=\mathrm{p}<0.05 ; * *=\mathrm{p}<0.01 ; * * *=\mathrm{p}<0.001$ 


\section{DISCUSSION}

The study presented demonstrates the amelioration of sperm morphology under MSOME criteria as well as improved motility and sperm concentration of IVF patients after oral supplementation with antioxidants and other micronutrients. The most remarkable benefit was observed for IVF patients with impaired semen parameters. Various publications have already suggested that restricted sperm parameters such as low sperm count, poor morphology or immotility of sperms are caused by a rise of reactive oxygen species (ROS) or ineffective ROS scavenging including malnutrition, inflammation, advanced age or exposure to toxic substances and endocrine disruptors (Eskenazi et al., 2005). Antioxidants, such as ascorbic acid, tocopheroles, carotenoides and micronutrients such as zinc, which is known as cofactor of glutathione peroxidases and superoxide dismutases (SOD1 and SOD3), have been demonstrated to be critically important for normal semen quality and reproductive function in a number of studies in both animals and humans (Eskenazi et al., 2005). They are thought to counteract the detrimental effects of oxidative stress on the spermatozoa (Ross et al., 2010). A number of studies have described beneficial effects of oral antioxidative treatment on sperm quality (reviewed by Ross et al., 2010).

These effects are thought to be brought about by protecting developing sperms from detrimental oxidative stress. In spite of the low number of IVF patients within the subgroups, this study clearly demonstrated the effects of a dietary supplement not only on conventional criteria of sperm parameters (according to WHO) but also on MSOME criteria and depicts the correlation of population subgroup and the outcome in terms of improved semen parameters. While oligo-, astheno or OAT patients experienced the most benefit of the dietary intake, the normozoospermic patients showed only slight but not significant improvements in the morphological sperm parameters.

These findings indicate that severe restriction in semen parameters might reflect more imbalances of the ROS/ antioxidant levels, possibly caused by environmental, lifestyle or genetic reasons. For example, it is known, that aberrant expression of the antioxidative-acting enzyme GPX4 in spermatozoa is considered as one of the causes of oligozoospermia in infertile men (Schneider et al., 2009; Chabory et al., 2010). Another crucial factor is the environmental pollution, which has increased continuously during the last decades, less in the industrialized, but in particular in the emerging economies. Most environmental toxicants have been shown to impair testicular spermatogenesis by inducing reactive oxygen species (Mathur \& D'Cruz, 2011). This is important as a decrease of sperm parameters and increase of DNA damage in the sperm as a result of oxidative stress has been linked to poor reproductive outcomes.

\section{CONCLUSION}

Consumption of antioxidative foodstuff such as fruits, minerals or essential amino acids was found to have a positive correlation with semen quality (Braga et al., 2012). During the last decade, it has become more and more clear, that not only personal factors like lifestyle, nutrition and genetic disposition have an impact on sperm quality but also increasing pollution and environmental factors impact on human fertility and the offspring. Therefore, couples who desire having children, in particular IVF patients, should be counselled to be aware of putative detrimental influences of environmental and lifestyle factors and the impact of their nutritional behaviour and intake of dietary supplements might have supportive effect, especially in men with poor sperm quality.

\section{Correspondence}

Nicolas Herbert Zech

Tel.: +43-664-2843996. E-mail: n.zech@ivf.at

Roemerstrasse 2, A 6900 Bregenz. Austria

\section{REFERENCES}

Acacio BD, Gottfried T, Israel R, Sokol RZ. Evaluation of a large cohort of men presenting for a screening semen analysis. Fertil Steril. 2000;73:595-97. Agarwal A, Allamaneni SS. Free radicals and male reproduction. J Indian Med Assoc. 2011;109:184-87. Review.

Balercia G, Buldreghini E, Vignini A, Tiano L, Paggi F, Amoroso S, Ricciardo-Lamonica G, Boscaro M, Lenzi A, Littarru G. Coenzyme Q10 treatment in infertile men with idiopathic asthenozoospermia: a placebo-controlled, double-blind randomized trial. Fertil Steril. 2009;91:1785-92.

Bartoov B, Berkovitz A, Eltes F, Kogosovsky A, Yagoda A, Lederman H, Artzi S, Gross M, Barak Y. Pregnancy rates are higher with intracytoplasmic morphologically selected sperm injection than with conventional intracytoplasmic injection. Fertil Steril. 2003;80:1413-19.

Blacksmith Institute, The World's Worst Polluted Places: The Top Ten of the Dirty Thirty; 2007. Available at: http://www. blacksmithinstitute.org/.

Braga DP, Halpern G, Figueira Rde C, Setti AS, Iaconelli A Jr, Borges $E$ Jr. Food intake and social habits in male patients and its relationship to intracytoplasmic sperm injection outcomes. Fertil Steril. 2012; 97:53-9.

Carlsen E, Giwercman A, Keiding N, Skakkebaek NE. Evidence for decreasng quality of semen during past 50 years. BMJ. 1992;305:609-13. Review.

Chabory E, Damon C, Lenoir A, Henry-Berger J, Vernet P, Cadet R, Saez F, Drevet JR.Mammalian glutathione peroxidases control acquisition and maintenance of spermatozoa integrity. J Anim Sci. 2010;88:1321-31. Review.

Ciftci O, Aydin M, Ozdemir I, Vardi N. Quercetin prevents 2,3,7,8 tetrachlorodibenzo-p-dioxininduced testicular damage in rats. Andrologia 2011. doi: 10.1111/j.1439 0272i.2010.01126.x.

Ciftci H, Verit A, Savas M, Yeni E, Erel O. Effects of N-acetylcysteine on semen parameters and oxidative/antioxidant status. Urology. 2009;74:73-76.

Eskenazi B, Kidd SA, Marks AR, Sloter E, Block G, Wyrobek AJ. Antioxidant intake is associated with semen quality in healthy men. Hum Reprod. 2005;20:1006-12.

Huang CY, Yao CJ, Wan.g C, Jiang JK, Chen G,. Zhonghua Nan Ke Xue. Changes of semen quality in Chinese fertile men from 1985 to 2008. 2010;16:684-88

Jenkins TG, Carrell DT. The sperm epigenome and potential implications for the developing embryo. Reproduction. 2012;143:727-34.

Koifman S, Koifman RJ, Meyer A. Human reproductive system disturbances and pesticide exposure in Brazil. Cad Saude Publica. 2002;18:435-45.

Kumar R, Venkatesh S, Kumar M, Tanwar M, Shasmsi MB, Kumar R, Gupta NP, Sharma RK, Talwar P, Dada R. Oxidative stress and sperm mitochondrial DNA mutation in idiopathic oligoasthenozoospermic men. Indian J Biochem Biophys. 2009;46:172-77.

Lewis SE, Simon L. Clinical implications of Sperm DNA damage. Hum Fertil (Camb). 2010;13:201-7. Review.

Lichtenfels AJ, Gomes JB, Pieri PC, El Khouri Miraglia SG, Hallak J, Saldiva PH. Increased levels of air pollution and a decrease in the human and mouse male-to-female ratio in São Paulo, Brazil. Fertil Steril. 2007;87:230-32.

Mahfouz R, Sharma R, Thiyagarajan A, Kale V, Gupta S, Sabanegh E, Agarwal A. Semen characteristics and sperm DNA fragmentation in infertile men with low and high levels of seminal reactive oxygen species. Fertil Steril. 2010;94:2141-46.

Mathur PP, D'Cruz SC. The effect of environmental contaminants on testicular function. Asian J Androl. 2011;13:585-91. doi: 10.1038/aja.2011.40. Review. 
Mohallem SV, de Araújo Lobo DJ, Pesquero CR, Assunção JV, de Andre PA, Saldiva PH,Dolhnikoff M. Decreased fertility in mice exposed to environmental air pollution in the city of Sao Paulo. Environ Res. 2005;98:196-202.

Multigner L, Oliva A. Secular variations in sperm quality: fact or science fiction? Cad Saude Publica. 2002;18:403-12. Review.

Nelson CM, Bunge RG. Semen analysis: evidence for changing parameters of male fertility potential. Fertil Steril. 1974;25:503-7. Oliva A, Spira A, Multigner L. Contribution of environmental factors to the risk of male infertility. Hum Reprod. 2001;16:1768-76.

Omu AE, Al-Azemi MK, Kehinde EO, Anim JT, Oriowo MA, Mathew TC. Indications of the mechanisms involved in improved sperm parameters by zinc therapy. Med Princ Pract. 2008;17:108-16.

Rasmussen PE, Erb K, Westergaard LG, Laursen SB. No evidence for decreasing semen quality in four birth cohorts of 1,055 Danish men born between 1950 and 1970. Fertil Steril.1997;68:1059-64.

Ross C, Morriss A, Khairy M, Khalaf Y, Braude P, Coomarasamy A, El-Toukhy T. A systematic review of the effect of oral antioxidants on male infertility. Reprod BioMed Online. 2010;20:711- 23.

Schneider $M$, Förster $H$, Boersma $A$, Seiler $A$, Wehnes $H$, Sinowatz $F$, Neumüller $C$, Deutsch $M J$, Walch $A$, Hrabé de Angelis M, Wurst W, Ursini F, Roveri A, Maleszewski M, Maiorino
M,Conrad M. Mitochondrial glutathione peroxidase 4 disruption causes male infertility. FASEB J.2009;23:3233-42.

Silva PF, Gadella BM, Colenbrander B, Roelen BA. Exposure of bovine sperm to pro-oxidants impairs the developmental competence of the embryo after the first cleavage. Theriogenology. 2007;67:609-19.

WHO Laboratory manual for the examination and processing of human semen, Fifth Edition.2010.

Vanderzwalmen $P$, Hiemer A, Rubner $P$, Bach $M$, Neyer A, Stecher $A$, Uher $P$, Zintz $M$, Lejeune B, Vanderzwalmen S, Cassuto $G$, Zech NH. Blastocyst development after sperm selection at high magnification is associated with size and number of nuclear vacuoles. Reprod BioMed Online. 2008;17:617-27.

Yauk C, Polyzos A, Rowan-Carroll A, Somers CM, Godschalk RW, Van Schooten FJ, Berndt ML, Pogribny IP, Koturbash I, Williams A, Douglas GR, Kovalchuk O. Germ-line mutations, DNA damage, and global hypermethylation in mice exposed to particulate air pollution in an urban/industrial location. Proc Natl Acad Sci U S A. 2008;105:605-10.

Zini A, de Lamirande E, Gagnon C. Reactive oxygen species in semen of infertile patients: levels of superoxide dismutase- and catalase-like activities in seminal plasma and spermatozoa. Int J Androl. 1993;16:183-88. 